\title{
MICRO- EN MACRO-ECONOMIE \\ (SCHETS ENER VERGELIJKING TUSSEN DE THEORIEEN VAN \\ PROF. TH. LIMPERG EN J. M. KEYNES)
}

door De L. Perridon

De aanleiding tot het schrijven van mijn artikel in de „Economie Contemporaine" was een discussie over het referaat van Prof. Mertens uit Leuven, hetwelk het boeiende en actuele vraagstuk „La politique du plein emploi et ses mérites" tot onderwerp had. (Congrès des Economistes de langue française, Paris, mai 1951).

Het viel mij op, dat de keynesiaanse theorie, zelfs in haar meest moderne ontwikkeling vele $z$ wakheden vertoont vooral met betrekking tot zekere onderwerpen, welke in nauw verband staan met hetgeen men in Nederland "Bedrijfseconomie" pleegt te noemen. Sommige interventies tijdens het debat deden het mij zeer gewenst voorkomen om een korte uiteenzetting te geven van Prof. Limperg's theoriën om zodoende de aandacht van de Franse economen hierop te vestigen. Zoals ik zeide in een ander artikel, leek mij de beste wijze hiervoor de magische naam van Keynes met die van Limperg in verbinding te brengen. Met bedoeld artikel hoopte ik tevens aan te tonen, dat er voor het in Frankrijk alom heersend sceptisime t.a.v. de bedrijfseconomie geen plaats is, daar Prof. Limperg en zijn leerlingen reeds lang erin geslaagd zijn een zuiver economische theorie voor het bedrijfsleven op te bouwen.

Een vergelijkende studie tussen Limperg en Keynes wordt ten zeerste bemoeilijkt door het feit, dat beide auteurs van een diametraal tegenovergesteld standpunt uitgaan. Keynes heeft zijn blik gericht op de maatschappelijke verschijnselen in hun geheel genomen, Limperg daarentegen beperkt zich tot de verschijnselen binnen de bedrijfshouding. Keynes omvat de gehele economische kringloop, Limperg alleen de productie. Vatten wij dit alles tesamen in de thans gebruikelijke terminologie, dan is Keynes essentieel macroscopisch en Limperg microscopisch. Op het eerste gezicht zijn er dus voldoende tegenstellingen, welke iedere poging tot vergelijking tot mislukking doemen.

Het eigenlijk doel van deze studie is dan ook na te gaan in hoeverre de Limpergiaanse opvattingen bevruchtend kunnen inwerken op de moderne theorie. Hiervoor evenwel is het nodig sommige inzichten van Keynes voor zover zij een bedrijfseconomisch karakter dragen aan een nauwgezet onderzoek onder het licht van de Amsterdamse theoriën te onderwerpen.

Gaan wij eerst na wat de diepere betekenis is van de twee begrippen welke het huidig denken beheersen. De microcosmos wordt gevormd door het individuele, de macrocosmos door de maatschappij. Tussen deze uiterste vormen staan tussenvormen als de groep (cooperaties, overheidsbedrijven enz.). Betrekt men deze in het debat, dan wordt de onderscheiding reeds vager. In feite heeft de economie steeds de verschillende subjecten bestudeerd. Het verdelingsvraagstuk toch is uiteindelijk een macroeconomisch probleem, maar het werd gezien vanuit het oogpunt van het individu en niet zoals tegenwoordig in categorieverband. Anderzijds is thans meer dan ooit duidelijk, dat wat geldt voor het individu nog niet geldt voor de maatschappij en omgekeerd. Mrs 
Robinson geeft als voorbeeld de spaarzaamheid: op individueel plan is zij een deugd, maar maatschappelijk bezien een ondeugd. Het is deze constatering welke de revolutie in onze wetenschap heeft gebracht.

Keynes, hoewel uitgaande van bovenaf, is verplicht de individuele ondernemer in zijn redenering te betrekken, maar hij neemt hem als de vertegenwoordiger van de categorie ondernemers. Het verschil met de traditionele opvatting (en met Limperg) is, dat Keynes de algehele vrijheid van handelen van het individu ontkent. In deze zin is Keynes' systeem op een mecanistische grondslag gevestigd. Hier hebben wij dus een eerste aanknopingspunt. Een tweede vinden wij in de onderscheiding tussen de micro- en macro-economie zelve. Wanneer men met de zwitserse phy sicus Charles Eugène Guye aanneemt, dat het de ,échelle d'observation (is) qui crée le phénomène, chaque fois que nous changeons d'échelle d'observation, nous rencontrons des phénomènes nouveaux" 1 ) dan volgt daar onmiddellijk uit, dat een exclusieve microscopische of macroscopische analyse tekort schiet om de economische verschijnselen adequaat te verklaren. Beide zijn innig met elkaar verbonden. Dit verband tussen bedoelde beschouwingswijzen maakt de hier voorgenomen studie mogelijk.

Nemen wij als uitgangspunt het centrale probleem van de economie: het waardeverschijnsel. De microeconomie bestudeert de acties en reacties van het subject tegenover de schepping van nieuwe waarden en tegenover de gegeven waarden, m.a.w. zij heeft het economisch handelen van de enkeling in diens functie van producent en consument (en soms groepen van individuen) tot voorwerp. De macroeconomie heeft de maatschappelijke waardevorming in haar geheel te verklaren, d.w.z. die waarden, welke voor het individu in de meeste gevallen data zijn. Tussen beide staat de producent: enerzijds is hij de schepper van nieuwe waarden, anderzijds (met de Staat) verdeler van het nationale inkomen. De gedachte van J. B. Say, dat de entrepreneur de centrale figuur van het economische leven is, blijkt heden ten dage ondanks de structurele veranderingen welke het ondergaan heeft, nog steeds juist te zijn. Een studie van de economische functie van de producent is dus alleszins gewenst. Tenslotte maakt de General Theory herhaaldelijk gebruik van bedrijfseconomische begrippen. Is de marginal efficiency of capital niet in feite een dergelijk begrip? Wordt de houding van de ondernemer t.a.v. het employment niet grotendeels bepaald door zijn winststreven en kostenvergelijking? Trouwens Keynes zelf brengt de bedrijfseconomie in het geding wanneer hij de noodzakelijkheid betoont van een productietheorie. (Chap. XXI)

Om echter ieder misverstand te voorkomen zij hier opgemerkt, dat het niet in onze bedoeling ligt om in het onderhavige artikel het keynesiaans systeem in zijn geheel te onderzoeken in het kader van de theoriën van Prof. Limperg. Niet bijv. de theorie, die wil, dat employment en inkomen de afhankelijke variabelen van het economisch systeem zijn zal hier worden besproken, maar alleen die punten, welke een bedrijfseconomisch aspect hebben. Verder dient men bij de bespreking van Keynes' theoriën (en trouwens van schrijver) steeds voor ogen houden, dat de "science économique n'est pas une science exacte et les critères manquent pour un tel jugement. Une théorie économique paraît plus simplement posséder une valeur relative plus ou moins grande, étant donnés ses prémisses, ses postulats, les préoccupations personnelles de son auteur, le milieu où elle a pris naissance, le cas qu'elle envisage, la méthode qu'elle utilise .....2). Wij komen thans tot het plan van ons artikel. In de eerste plaats zul- 
len wij de door beide auteurs gebruikte methoden bestuderen en daarbij in het bijzonder de grondslagen van hun theoriën bespreken. Dit zal het onderwerp zijn van Sectie I. Daarna zullen wij de kostentheorie onder de loupe nemen en het keynesiaanse begrippenstelsel critisch bespreken. (Sectie II) terwijl de marginal effeciency of capital in Sectie III ter sprake zal komen. Waar de General Theory het begrip vervangingswaarde hanteert zal dit t.g.p. aan een korte beschouwing worden onderworpen.

\section{DE THEORETISCHE GRONDSLAGEN.}

Dudley Dillard heeft de theoretische houding van Keynes als volgt getypeerd: „Whereas the classical economists are concerned with rational behaviour in a rational world, Keynes is concerned with rational behaviour in an irrational world 3 ). In deze passage is de keynesiaanse revolutie juist gekarakteriseerd. Teneinde zich rekenschap te kunnen geven van de reële economische verschijnselen zoals deze zich aan hem voordeden tijdens het schrijven van zijn meesterwerk, heeft Keynes niet geaarzeld met de methode door zijn voorgangers gebruikt, nl. de idealisering van het economische leven, radicaal te breken. In dit opzicht kan men het met Keynes eens zijn wanneer hij zijn voorgangers als Klassieken aanduidt.

Het keynesiaanse tijdperk, hetwelk wij nu beleven wordt dan ook gekenmerkt door een positieve en quantitatieve bestudering van de economische verschijnselen alsook door het leggen van een nauw verband tussen wat men de analytische economie zou kunnen noemen en de toegepaste economie. Door deze nieuwe probleemstelling is de homo oeconomicus opnieuw actueel geworden. Zoals bekend hebben de Klassieken deze geestesconstructie als werkhypothese aanvaard. Veel is over het al dan niet juiste van deze hypothese geschreven; voor- en tegenstanders deze laatsten vooral - hebben vaak uit het oog verloren, dat het om een werkhypothese ging. De homo oeconomicus is een conceptualisering van de reële mens, $z$ ij neemt slechts een bepaald aspect van de mens in ogenschouw en om deze reden kunnen de theoriën, welke op haar zijn opgebouwd nooit een afdoende verklaring geven van de reële verschijnselen welke ongemeen complex zijn. Het economische kan niet worden losgetrokken van het sociale. Iedere poging daartoe is bij voorbaat tot mislukken gedoemd, wanneer men meent op die wijze rekenschap te kunnen geven van de concrete verschijnselen. De klassieke werkwijze maakte de economie tot een sociale physica waar dezelfde methoden zouden kunnen worden aangewend als in de eigenlijke physica. Hoewel het hier ondoenlijk is het voor en tegen van deze thesis te bespreken - zij heeft bovendien een draagwijdte welke de economie overtreft - daar zij het geheel van de sociale wetenschappen betreft, dienen wij evenwel niet te vergeten. dat de figuur van de homo oeconomicus in feite de hypostasis van een algemeen beginsel is hetwelk juist het object van de economische wetenschap aangeeft. De homo oeconomicus toch is de mens die onder alle omstandigheden het te brengen offer in verband brengt met de daarvan afhangende opbrengst en slechts dān het noodzakelijke offer brengt wanneer dit kleiner is dan de verwachte opbrengst. In de Limpergiaanse formulering is van de homo oeconomicus geen sprake meer en terecht spreekt de amsterdamse hoogleraar van het economisch principe. In deze nieuwe versie is het mogelijk dit principe in te voegen in de skala der principen, welke de mens in zich draagt. De hypostasis van de Klassieken maakte 
dit niet mogelijk, daar men vergat, dat de mens een ens universalis is, welke de algemene beginselen waardeert, d.w.z. deze in een bepaalde rangorde plaatst. Hiervoor was in de klassieke opvatting geen plaats en aldus schoot zij in haar zending tekort. Verder kan men nog opmerken, dat het geincrimineerde begrip deel uitmaakte van een theorie, welke essentieel miscroscopisch was ingesteld. Het verdient derhalve aanbeveling om te onderzoeken of het ook relevant is voor de macroeconomie.

Prof. Kleerekoper gaat bij de formulering van het beginsel van de behoeftenbevrediging uit, waardoor het meer begrensd is dan in de formule welke hierboven werd gegeven, welke, wij verhelen het niet, ook op de psychologie van toepassing is. Het nadeel van Kleerekoper's formulering is, dat zij niet toepasselijk is op de producent. De activiteit van deze laatste is immers slechts middellijk op zijn behoeftenbevrediging gericht ${ }^{4}$ ). Maar het is klaarblijkelijk de bedoeling van Kleerekoper het economisch aspect van het beginsel te belichten en zodoende ieder ",ongeoorloofd psychisme" a priori uit te sluiten. Onder deze reserve kunnen wij zijn omschrijving aanvaarden en zeggen, dat de mens ,streeft bij zijn bewuste activiteit op zijn behoeftenbevrediging gericht ernaar om een zo groot mogelijk overschot van zijn opbrengsten boven zijn offers te verkrijgen ${ }^{5}$ ). Prof. Kleerekoper neemt terecht dit beginsel als het postulaat van onze wetenschap aan en hij voegt hieraan toe, dat ieder verschijnsel, hetwelk niet geheel en al tot bedoeld beginsel herleidbaar is, niet voor een zuiver economische verklaring in aanmerking komt. In de beschouwing van Kleerekoper komt zeer duidelijk tot uitdrukking, dat het economische principe betrekking heeft op het bewust handelend individu. Het houdt tevens in hoe rationeel gehandeld dient te worden, derhalve een voorschrift, een regel 6 ). De maatschappij als zodanig is geen denkend of rationeel wezen, $z$ ij is een collectiviteit van rationele mensen zonder een apart of eigen specifiek bewustzijn 7). Hieruit volgt noodzakelijkerwijze, dat er voor haar geen economisch beginsel kan bestaan in dezelfde zin als voor het individu. Zoals hierboven werd aangetoond is het verschijnsel een schepping van de échelle d'observation. Dit is eveneens het geval met het economisch beginsel, het krijgt een andere inhoud. De ondernemer of consument kan op de lange duur niet boven zijn stand leven, voor de wereldmaatschappij is zulks (waarschijnlijk) niet het geval. Hieruit valt te concluderen, dat het economisch beginsel onder alle omstandigheden door het individu moet worden toegepast. Voor de maatschappij in haar geheel ligt de zaak anders omdat haar uiteindelijk doel niet economisch is; het economische is ondergeschikt aan een hoger doel t.w. het algemeen welzijn. Dit welzijn nu kan soms alleen bereikt worden door oneconomisch te handelen. Keynes heeft dit terdege ingezien toen hij zijn bekend voorbeeld gaf van goud in de grond te stoppen en dit later er weer uit te halen om aldus de economische activiteit tot nieuw leven te wekken. Het verwerpen van het economisch beginsel voor de maatschappij houdt evenwel niet in, dat het alleen maar betrekking zou hebben op het individu. Als ieder gesubordineerd beginsel krijgt het eerst dan zijn volle betekenis wanneer men overgaat tot de economische handeling. Zo besloten wordt tot het bouwen van ziekenhuizen en scholen in plaats van vergroting van de productiecapaciteit, dan wordt een keuze gemaakt tussen een (hoger) speciaal doel en een economisch doel, maar zodra men tot de economische handeling, het bouwen, overgaat, wordt het economisch beginsel relevent. Het is duidelijk, dat het beginsel steeds van toepassing is op een gegeven situatie. Dit zien wij o.a. bij Keynes. In zijn 
theorie is geen plaats voor het beginsel. $Z_{\mathrm{ijn}}$ systeem is volkomen mecanistisch opgebouwd: de geldcreatie bijv. heeft niet plaats om een economisch maar om een sociaal doel te bereiken nl. het absorberen van inactieve werkkrachten. Dus, om dit sociale doel te bereiken, maakt Keynes terecht gebruik van de economische krachten. In dit opzicht staat hij lijnrecht tegenover Marx, want niet het economische beheerst het sociale gelijk Marx doceerde, maar het sociale het economische. Had Marx gelijk, dan zouden de economische krachten niet ten dienste gemaakt kunnen worden van het sociale.

Alleen wanneer Keynes het individu in zijn redenering betrekt maakt hij uitdrukkelijk gebruik van het economisch beginsel. $Z_{i j n}$ motieventheorie vormt hiervan een voorbeeld. Zo zegt Keyres o.a.: „, de beslissing om al dan niet op te potten wordt niet willekeurig genomen of zonder acht te slaan op de voordelen welke een afzien van de liquiditeit medebrengt, zij is het resultaat van het in de weegschaal werpen van de voordelen, welke ieder oplossing geeft, men mag derhalve niet uit het oog verliezen wat zich in de andere schaal bevindt" (General Theory, trad. franc. p. 189).

De hierboven ontwikkelde gedachtengang is trouwens in overeenstemming met het onderscheid naar voren gebracht in de inleiding van dit artikel. De economie als positieve en analytische wetenschap is wertfrei en behoort tot de groep van de zijnswetenschappen, maar als normatieve wetenschap tot de waardewetenschappen 8 ).

Keren wij thans terug tot Limperg. $Z_{i j n}$ theorie is, zoals bekend, opgebouwd op het economisch beginsel, dat hier zowel dient tot omschrijving van het formele object van onze wetenschap als tot regel van het economisch handelen. Hierdoor heeft deze theorie een finalistisch karakter, hetwelk wij ook bij Keynes gevonden hebben zij het ook met een volkomen verschillende inhoud. Bij Keynes gaat het om een economische therapeuthie te vinden voor de zieke maatschappij; Limperg daarentegen gaat uit van een gezonde toestand en stelt zich als doel: de ontleding van het mecanisme van de productie om door die analyse de middelen te verkrijgen om zo rationeel mogelijk te produceren. Hoewel dus hun uitgangspunt verschilt zoeken beide auteurs een en hetzelfde doel: een gezond economisch stelsel.

Met betrekking tot de methoden kunnen wij kort zijn. Limperg kunnen wij als een classicus beschouwen. Uitgaande van een a priori aangenomen regel is zijn gehele theorie, zowel de analytische als de toegepaste, daar aan onderworpen. $Z_{i j n}$ methode is deductief alhoewel hij voortdurend de door de redenering verkregen resultaten met de praktijk vergelijkt. Waar evenwel theorie en praktijk niet met elkaar overeenstemmen, aar zeit hij niet het theoretisch inzicht als enig juiste te beschouwen. In dit opzicht is zijn systeem een idealisering van het economische leven. Keynes van zijn kant gaat, als men het zo noemen mag, phenemenologisch tewerk. Vanuit het brute verschijnsel tracht hij tot de kern door te dringen. Terwijl men bij de oudere theoriën naar de opbouw van de afzonderlijke verschijnselen zoekt om aldus een inzicht te verkrijgen van het gehele economische leven, (hetgeen evenwel niet gelukt is, zoals duidelijk blijkt uit de afzonderlijke behandeling van het geldprobleem), gaat de Brit uit van het gehele nationale inkomen om naar de samenstellende elementen af te dalen. Deze werkwijze is geheel in de lijn van het Britse empirisme en de common sense, welke altijd meer belang heeft gehecht aan het concrete verschijnsel dan aan de theoretische grondslagen. 
Concluderend kunnen wij vaststellen, dat wat werkwijze en uitgangspunten betreft onze auteurs volkomen verschillen, maar overeenstemmen in hun doelselling $\mathrm{nl}$. regels op te sporen voor een rationeel economisch handelen.

\section{DE KOSTEN-THEORIE.}

In zijn theorie onderscheidt Keynes twee kostencategoriën al naar gelang de kosten al dan niet gewild kunnen worden door de producent. Prof. Jean Marchal heeft in zijn boek "Le mécanisme des prix" 5 kostensoorten bij Keynes gevonden.

1. de factorkosten door Keynes gedefinieerd als: ,het bedrag dat de ondernemer heeft betaald aan andere productiefactoren in ruil voor hun diensten. (hier zien wij reeds, dat Keynes alleen de historische kostprijs op het oog heeft) ${ }^{9}$ ).

2. de supplementaire kosten, welke voortkomen uit een waardevermindering van het productieapparaat voorzover zij niet opgenomen is in de verbruikskosten. Het symbool is V. Deze kosten zijn onvrijwillig, de ondernemer moet ze ondergaan.

3. de intrestkosten: Keynes geeft hier geen eigenlijke omschrijving, welke direct verband houdt met ons onderwerp, maar Marchal schijnt deze in zijn verdeling op te nemen omdat zij vaak voorkomen in de kostprijsberekening. Zo schrijft Marchal: „pour se procurer les bâtiments, les machines ...... qui constituent son équipement, l'entrepreneur a été contraint d'empunter ...... du capital monétaire. A ce capital monétaire, il est obligé, par contrat, de payer un intérêt. En verderop zegt hij „Le charge qui résulte pour lui de ce fait" hangt af enerzijds van de aanschaffingskosten van de productiecapaciteit en anderzijds van de rentevoet. Deze rente zou dus een vaste last vormen voor de productie. Hier kunnen wij nogmaals herhalen, dat er van vervangingswaarde geen sprake is, maar belangrijker is, dat noch Keynes noch Marchal zich rekenschap geven van de natuur van het renteverschijnsel. Limperg is, zoals men weet, tot de slotsom gekomen, dat rente een noodzakelijk begeleidingselement is van iedere kostencategorie. Rente wordt betaald omdat men cver schaarse vreemde koopkracht wil beschikken. De aanbieder van koopkracht verlangt een vergoeding, maar de ondernemer, die eigen koopkracht aanwendt, ziet van deze vergoeding af. Deze laatste aanwending van koopkracht heeft een onttrekking van dezelve op de vermogensmarkt ten gevolge. Terecht merkt Kleerekoper op, dat de ondernemer een winst moet maken (wil hij economisch rationeel handelen) groter dan de rente, welke hij op de markt kan krijgen. Calculeert hij volgens de limpergiaanse opvatting, dan betekent iedere winst een overschot op de heersende rentevoet, daar in de ksotprijs deze laatste is opgenomen. Rente is derhalve geen zelfstandige kostencategorie en dient dientengevolge als zodanig te worden verworpen. (men kent de leer van de Amsterdamse school t.o.v. leenrente)

4. risicokosten: deze worden door de brutowinst gedekt. $Z_{i j}$ zouden kunnen worden gequalificeerd als die offers, welke voortspruiten uit de onzekerheid waarin de ondernemer verkeert t.a.v. toekomstige productieprocessen. Het is de functie van de reserves aan deze onzekerheid tegemoet te komen. Reeds uit het feit, dat zij a posteriori berekend worden en dat $z$ ij niet in causaal verband staan met vorige 
productieprocessen moet ook deze kostengroep worden verworpen. Het risico wordt betaald door een deel van de winst, ware er geen risico dan was de winst immoreel en bijgevolg te veroordelen.

5. Gebruikskosten: deze hangen geheel af van de ondernemer. $Z_{i j}$ ontstaan door het gebruik van de productiecapaciteit, maar de grootte ervan wordt bepaald door de lopende normale onderhoudskosten daarvan af te trekken. Hier valt op te merken, dat Keynes dicht bij de theorie van het werkeenhedenfonds van Limperg staat, want hij betrekt in de berekening van deze kosten de verwachte toekomstige waarde van de productiecapaciteit. Alleen ziet hij het logisch en natuurlijk verband niet tussen de eerste en laatste werkeenheid waardoor hij niet in staat is aan zijn theorie de finishing touch te geven zoals Limperg.

$\mathrm{Na}$ bovenstaande uiteenzetting van de voornaamste kostencategoriën welke Keynes onderscheidt, kunnen wij thans overgaan tot een critische beschouwing van de voornaamste passages uit Chap. VI hetwelk handelt over de begripsbepaling van het inkomen, het sparen en het investeren.

Volgens Keynes zijn er twee methoden, welke in staat stellen het inkomen van de ondernemer te bepalen. De een gaat uit van de productie, de andere van de consumptie. Beide geven hetzelfde resultaat, hetgeen volkomen logisch is, want de uitgaven van de een zijn inkomsten voor de ander, aan de productiestroom correspondeert een tegenovergestelde consumptiestroom. Uiteraard interesseert ons hier hoofdzakelijk de eerste methode. Gedurende het boekjaar (period) maakt de onderneming een zekere omzet (A). Van deze omzet moeten zekere bedragen worden afgetrokken om het inkomen te berekenen. In de eerste plaats een bedrag $A_{1}$ hetwelk de uitgaven vertegenwoordigt door de onderneming gedaan om grondstoffen en andere eindproducten van de hoger gelegen productiecellen aan te schaffen. Op het einde van het boekjaar bezit de ondernemer een bepaald kapitaal (voorraden, circulerend kapitaal (G)). De totale waarde: $A+G-A_{1}$ moet worden verminderd met de kosten van de verschillende factoren, welke tezamen de eigenlijke kostprijs vormen. $Z_{\mathrm{ij}}$ wordt gevormd door de volgende elementen:

B1: de sommen welke besteed zouden worden ook al werkt de onderneming niet, het zijn dus de zuivere onderhoudskosten van de outillage. In deze veronderstelling is de waarde van de outillage op het einde van het boekjaar $\mathrm{G}^{\prime}$; hieruit volgt dan, dat $\mathrm{G}^{\prime}-\mathrm{B}^{1}$ de maximum netto-waarde is, welke mogelijk geweest zou zijn om de outillage te behouden als deze niet gediend had om de omzetwaarde $\mathrm{A}$ te produceren.

U: waar echter normaliter de outillage wel gebruikt wordt, is haar eindwaarde lager. Het verschil duidt men aan met de verbruikskosten (usercost) $: U=\left(G^{1}-B^{\prime}\right)-\left(G-A_{1}\right)$.

Deze verbruikskosten stellen dus voor het bedrag hetwelk door de ondernemer aangewend wordt om de productie te verkrijgen en door verkoop waarvan hij de ontvangsten A kan verkrijgen. Maar de ondernemer heeft nog andere uitgaven, welke met de productie in verband staan: deze worden voorgesteld door de reeds genoemde fac. torkosten F. De kostprijs of ,prime cost" is dus: U + F.

Tot zover blijft Keynes zeer klassiek. Immers in de praktijk heeft men 
ook de gewoonte om uit te gaan van de omzetwaarde. Het specifieke van Keynes ligt hier meer in de door hem geschapen nieuwe terminologie alsook in het door hem gestelde doel: het nationale inkomen. Zoals reeds opgemerkt onderscheidt Keynes vrijwillige en onvrijwillige kosten. Aan de verbruikskosten $U$ moet nog worden toegevoegd de supplementary cost welke voortvloeit uit de depreciatie (V) van de outillage, welke vermindering de ondernemer niet in de hand heeft. Het netto-inkomen van de ondernemer is dan ook: $A-(U+F+V)$.

Echter, zo merkt Keynes terecht op, is dit netto-inkomen nog niet gelijk aan het verdeelbare inkomen. In de eerste plaats is $\mathrm{V}$ berekend voor de voorzienbare kosten, waarvan de grootte nog niet is vastgesteld; men dient nog rekening te houden met de onvoorzienbare verliezen. Deze kosten komen ten laste van de kapitaalrekening, de reserverekeningen hebben als functie deze verliezen op te vangen. Over de berekening zelf zegt Keynes, dat „het bedrag van deze kosten afhangt van de keuze van de berekeningswijze". Deze oplossing is evenwel zeer onvoldoende. Keynes brengt onder $V$ twee hetegorene offers tezamen, welke voortvloeien uit een onvoorzienbare depreciatie van het kapitaal waarover de ondernemer beschikt, alsook die welke het gevolg zijn van het feit, dat de grootte van sommige voorzienbare offers nog niet bekend is. V, zo kan men zeggen omvat zowel de ,reserves" als de "voorzieningen" en is geen element van de kostprijs.

Deze opmerking kan men in verband brengen met de critiek, welke Dr A. I. Diepenhorst in zijn recente dissertatie geleverd heeft op zekere definities van de kostprijs welke iedere onzekerheid uitsluiten. Zoals men weet heeft de kostprijs de dubbele functie van een steunpunt te vormen voor de vaststelling van de verkoopprijs, en de contrōle op de efficientie van de productie mogelijk te maken. De eerste functie is uit de aard der zaak de belangrijkste. Volgens sommige definities zou de kostprijs de waarden van het goed aangeven op het moment van de ruil. Dit houdt de veronderstelling in, dat alle kosten op het moment van de ruil bekend zijn. Dit is zelfs in een stationnaire economie in tegenspraak met de feiten. Volgens de werkeenhedentheorie zijn alle werkeenheden met elkaar solidair, de juiste waarde van de werkeenheden wordt daarom alleen bekend op het moment van de afdanking; zolang de machine in dienst is weet de ondernemer weliswaar haar waarde van het moment, maar stel, dat een waardestijging over een of twee jaar plaats vindt, dan volgt daaruit dat de ondernemer zijn werkeenheden te laag gecalculeerd heeft 10). De onzekerheid brengt de ondernemer ertoe om zekere voorzorgsmaatregelen te nemen. Daar de bedrijfseconomie een realistische theorie wil zijn, moet haar begrip kostprijs rekening houden met hetgeen door de praktijk en de empirie als juist beschouwd wordt en door de theorie niet afgewezen kan worden. Het is theoretisch onvoldoende te volstaan met de simpele opmerking: de functie van de brutowinst is om als buffer te dienen. Dit is op zich wel juist, maar het eigenlijke probleem van de hoogte van de winstcalculatie is hiermede niet opgelost. Het vraagstuk wordt zodoende verschoven. Het blijft evenwel de vraag of een juiste oplossing überhaupt mogelijk is. Naar onze mening kan een juist antwoord niet worden gegeven omdat de bepaling van de grootte van de reserves grotendeels afhangt van psychologische factoren, welke van nature niet voor meting in aanmerking komen. Hiermede is tevens de opvatting van de bedrijfseconomie als zuiver quantitatieve wetenschap afgewezen. Het is een gelukkig teken voor de vitaliteit van onze discipline, dat problemen als door 
Diepenhorst opgeworpen, alsnog kunnen worden gesteld. Het bewijst, dat deze tak van de economie nog niet in een dogmatisch stadium is gekomen.

Terugkerend tot Keynes constateren wij, dat ook bij hem het bewustzijn van een onzekerheidselement in de economie bij het vaststellen van het nationale- en privé-inkomen.

Wat de limpergiaanse theorie betreft kunnen wij kort zijn wegens haar grote bekendheid in Nederland. De hoeksteen van deze theorie wordt gevormd door de definitie zelve van de kostprijs. De regieur waarmede zij geformuleerd wordt maakt het Limperg mogelijk een theorie op te bouwen welke de gehele economische activiteit van de onderneming omvat. Het is bij deze theorie niet mogelijk om een onderdeel eruit te lichten ter nadere bestudering. Aan de kostprijstheorie is een standaardtheorie gekoppeld, alsmede een financierings- en organisatietheorie, welke alle verbonden zijn door het imperatief van het economisch beginsel. Hierin ligt voor ons het fundamentele verschil tussen de traditionele theorie en de door Limperg opgestelde. Hoewel practisch alle theoriën het economisch principe impliciet tot grondslag hebben, heeft geen enkele theorie zo de nadruk hierop gelegd als de limpergiaanse. Wat de kostprijs betreft spreekt de definitie daarvan voor zichzelf: de kostprijs is nl. de som van de offers welke noodzakelijk zijn om een bepaald goed op een gegeven moment ter markt te brengen. Merken wij allereerst op, dat deze definitie universeel is; $z \mathrm{ij}$ is zowel van toepassing op de dienstverlening als op de landbouw - en industriële producten. Uit theoretisch oogpunt is dit reeds van het allergrootste belang. In Frankrijk, waar men voor het onderwijs van de landbouwhuishoudkunde aparte leerstoelen heeft ingericht, behoort dit vak nog steeds tot de beschrijvende wetenschappen; men bepaalt zich hoofdzakelijk tot een analyse van de marktprijsvorming.

Vervolgens zij opgemerkt, dat de kostprijsdefinitie in feite twee definities inhoudt: de definitie van de kostprijs zelve en die van de kosten, welke de noodzakelijke kosten voorstellen. Hiermede heeft Limperg de grondslag gelegd voor een efficientie-theorie door ieder offer, dat niet aan de gestelde eis voldoet als een verspilling te beschouwen. Door de zaken zo scherp te stellen heeft hij de economen en practici gedwongen meer strengheid te brengen in hun redeneringen, maar wat nog belangrijker is hij heeft de aandacht gevestigd op een zeer onjuiste opvatting in de praktijk, welke alleen de materiële uitgaven als kosten beziet. Het criterium voor de kosten is niet langer de uitgave, maar het noodzakelijk offer, zelfs wanneer dit niet met een uitgave gepaard gaat. Wij vragen ons af of de invoering van het onzekerheidselement niet de functie van de kostprijs als steunpunt voor de prijsvastzetting verzwakt. Zoals opgemerkt schuilt er een zekere dosis willekeur in de bepaling van de grootte van de bruto-winst. De tweede functie, die van efficientie-meter, wordt evenwel niet door dit element beïnvloed (behalve misschien de kosten van de duurzame productiemiddelen).

Ten derde sluit deze definitie de vervangingswaarde in door de kostprijs vast te stellen op het moment van de (economische) ruil. De grootte van de kostprijs op dat ogenblik vormt het steunpunt voor het waardeoordeel van de ondernemers. Wanneer wij deze definitie met de ,prime cost" van Keynes vergelijken, dan valt het in de eerste plaats op, dat Keynes, zoals trouwens alle sociaal-economen, geen zuiver begrip van kosten heeft. $Z_{i j}$ zijn voor hem uitgaven zonder meer. $W_{i j}$ zijn derhalve gerechtigd alle door Limperg en zijn school aan de theorie van de histo- 
rische kostprijs gerichte critiek ook aan Keynes te adresseren. Ware Limperg's theorie Keynes bekend geweest, dan zou naar alle waarschijnlijkheid het VI de hoofdstuk van de General Theory er anders uit gezien hebben. Ongetwijfeld zou Keynes dan hebben begrepen, dat het inkomen van de ondernemers niet op zo eenvoudige wijze kan worden berekend. Het is niet voldoende te stellen, dat $\mathrm{G}$ een bepaalde waarde heeft, dat $B^{\prime}$ de onderhoudkosten zijn en $G^{\prime}$ de maximum netto-waarde van de outillage is, want, hetgeen Keynes niet doet, er dient verklaard te worden of $\mathrm{G}$ de werkelijke waarde vertegenwoordigt op het einde van het boekjaar of de comptabele waarde. Alleen reeds de grootte van V zal hierbij worden beïnvloed en daarmede de vermogensrekening. Immers de waardeverschillen $z$ ijn reeds in de kostprijs verrekend, terwijl deze voor Keynes in $\mathrm{V}$ zijn opgenomen. $\mathrm{V}$ zal dan ook zuiver en alleen als reserverekening dienst kunnen doen.

De theorie, welke hieruit voortvloeit, schijnt ons van het grootste belang voor de wetenschap van de openbare finantiën en de economische politiek. Men bedenke slechts, dat een algemene toepassing van Limperg's theorie het mogelijk zal maken de conjunctuur op de voet te volgen door de algemene dynamisering van de nationale en privé comptabiliteit. De gecompliceerde redenering van Keynes is een voortvloeisel van het feit, dat hij een revolutie in de economische denkwijze heeft gebracht welke te vergelijken is met de kantiaanse in de philosophie. De traditionele wijze van de inkomen-berekening gaat uit van de omzet en vermindert deze enkel en alleen met de verschillende kostenelementen waaronder de afschrijvingen, berekend op historische aanschaffingswaarde. In de limpergiaanse gedachte laat men weliswaar dit criterium los, maar men houdt geen rekening met de B' kosten. De opvatting van Keynes, welke een zeer juiste gedachte inhoudt nl. om de waarde van de outillage naar voren te brengen wanneer deze niet productief werkt, is hem waarschijnlijk ingegeven door de omstandigheid, dat vele fabrieken gesloten waren of slechts met een gedeelte van hun capaciteit werkten toen hij zijn beroemd werk schreef. $Z_{i j}$ zijn in feite de constante (onvrijwillige) kosten van de maatschappelijke productiecapaciteit. Bij een normale bedrijfsdrukte spelen zij bedrijfseconomisch gezien practisch geen rol; slechts alleen dan wanneer de ondernemer besluiten moet om al dan niet te liquideren. Het gevaar van deze keynesiaanse theorie is echter, dat zij streeft naar een kostprijstheorie, welke nog enger is dan die van Limperg, daar zij de B' waarde niet insluit. (deze kosten zouden dus uit de brutowinst moeten worden gedekt). Wij hebben hier een illustratie van de door ons reeds in de inleiding naar voren gebrachte ,échelle d'observation" waardoor sommige verschijnselen geboren worden of verdwijnen met de hoogte van de observatiepost.

\section{DE ,MARGINAL EFFICIENCY OF CAPITAL”.}

Volgens Keynes is het de marginale efficiency van het vermogen en de rentevoet, welke het volumen van de investeringen bepalen.

Over de rente-theorie kunnen wij kort zijn. Keynes heeft hier alleen een verfijnde theorie gebracht van vraag en aanbod op de vermogensmarkt door zijn motieven-theorie hierin op te nemen. Zeker, het is Keynes gelukt om op harmonieuse wijze de monetaire theorie in de sociale economie te voeren, doch wat de rente-theorie zelve betreft is deze niet zozeer een nieuwe theorie dan wel een synthese van alle voorgaande theo- 
riën. Met zijn antwoord op de bekende vraag: waarom rente betaald kan worden overtreft hij evenwel de oostenrijkse school en die van Cambridge. Zoals bekend luidt dit: omdat het geleende vermogen bevruchtend werkt voor de lener 11). Alleen wat de hoogte van de rentevoet aangaat steekt hij de oudere theoriën in een nieuw kleed door de stelling te poneren, dat de rente nooit hoger kan zijn dan de marginale efficiëncy van het vermogen. Terecht heeft Marchal in zijn college 1949/50 erop gewezen, dat in feite zulks neerkomt op een nieuwe benaming voor de natuurlijke rentevoet of de evenwichtsvoet van de zweedse school van Wicksell (wirr werken Keynes naar zijn zeggen niet gekend heeft).

De amsterdamse school heeft terecht aangedrongen op het feit, dat rente en winst niet met elkaar verward mogen worden. De marginale efficiency van het vermogen is de winst, welke de ondernemer denkt te kunnen maken door het in het bedrijf stellen van een additioneel kapitaalgoed. Deze theorie is in feite zuiver oostenrijks in die zin, dat hier een marginale berekening wordt gemaakt welke Limperg in zijn afscheidcollege en daarna Prof. J. Mey in dit blad aan een grondige critiek hebben onderworpen. Dudley Dillard (op. cit. p. 40) geeft een zeer duidelijk voorbeeld van de betekenis van dit begrip: de marginale efficiency, zo zegt hij, is de ,expected rate of percentage profit per year on real investments of the most efficient type". Hij verduidelijkt dit met navolgend voorbeeld: stel, dat bij een toenemende bevolking een gebouw kan worden neergezet, dat $\$ 20.000$. - kost en $\$ 1200$. - per jaar opbrengt, terwijl de afschrijvings- en onderhoudskosten $\$ 200$. - per jaar bedragen, dan is de jaarlijkse opbrengst $\$ 1.000 .-$. Wanneer de rentevoet $4 \%$ is, dan is het gebouw $\$ 25000$. - waard. Hieruit volgt, dat het voordeliger is om $\$ 20.000$ te lenen tegen $4 \%$ en het gebouw neer te zetten waardoor men $\$ 200$. - per jaar extra verdient, want dan immers maakt men $5 \%$ van zijn geld. Dillard vervolgt: „If 5 per cent is the highest rate of return which can be assured from any type of real investment, the marginal efficiency of capital in general is 5 per cent ...... If the cost of construction of a new asset is less than the purchase price of the old asset of the same type, it will be profitable to build a new one rather than to buy the old one".

In de eerste plaats kan men constateren, dat hier het probleem van de vervangingswaarde wordt gesteld. Hoe kan, waar er zich slechts één prijs op de markt vormt, er een prijsverschil bestaan tussen oud en nieuw wanneer beide eenzelfde opbrengst geven. Het voorbeeld van Dudley Dillard is juist daarom zeer treffend gekozen, omdat het de onjuistheid van de theorie duidelijk onderstreept. Het is onwaarschijnlijk, dat de extra-vermogensaanwas van $\$ 5.000$. - de geldschieters er niet toe zou brengen zelf tot bouwen over te gaan nu de bouwer een vermogen van $\$ 5.000$. - in de schoot geworpen krijgt. Wat door Keynes (en Dillard) evenwel niet ingezien wordt, is dat deze $\$ 5.000$. - de waarde van de dienstverlening voorstellen. De aanbouw heeft als kostprijs een waarde van $\$ 20.000$. - maar de waarde van het gebouw als dienstverleningsobject bedraagt $\$ 25.000$. - Het verschil ad $\$ 5.000$. - kan economisch verklaard worden als zijnde de waarde ontstaan door het scheppen van het dienstverlenings-object, welke een gekapitaliseerd inkomen van $\$ 200$. - voorstelt à $4 \%$.

Keynes gaat bij de marginale efficiency uit van de historische kostprijs. Indien men aan deze laatste vasthoudt, kan de prijs van een nieuw goed lager zijn dan die van een oudere. Het schijnt Keynes ontgaan te 
zijn, dat hier vermogensvernietiging plaats heeft. Het is verwonderlijk, dat de sociaal-economen niet hebben ingezien welk een profijt er te trekken valt uit de onderscheiding tussen kapitaal en vermogen en uit het feit. dat de grootte van de laatste functie is van de waarde van de eerste. Men verwart zodoende het teniet gaan van vermogen met kapitaalsve:nietiging. Globaal gezien is het voor de economische politiek van het grootste belang uit bovengenoemde onderscheiding de noodzakelijke consequenties te trekken. Subventies aan sommige industriën zijn economisch onverantwoordelijk wanneer $z \mathrm{ij}$ alleen ten doel de vermogensinstandhouding te verzekeren. Subventies zijn dan alleen, en dan nog onder bepaalde voorwaarden, nuttig en verantwoord, wanneer zij kapitaalsvernietiging verhoeden. Per slot van rekening is vermogen een nominaal iets, terwijl kapitaal daarentegen een concreet bestanddeel vormt van de nationale rijkdom. Aldus dient de economische politiek op instandhouding van het economisch potentieel gericht te zijn en niet op instandhouding van (nominaal) vermogen. De waarde-theorie, zoals zij door Limperg en zijn school is ontwikkeld, brengt dit verschil duidelijk naar voren en haar integratie in de sociale economie kan zodoende op deze bevruchtend werken.

In de tweede plaats valt op te merken, dat de vervangingswaarde van "old asset" een wijziging ondergaat, wanneer een nieuw een grotere waarde heeft; het vermindert in waarde, wanneer de creatie van een nieuw kapitaal goed een kleinere waarde heeft dan de aanschaffingsprijs minus afschrijvingen van het oude. De in het boven geciteerde voorbeeld gevolgde redenering is derhalve onjuist; de waarde van de reeds bestaande goederen volgt die van de nieuw geschapene, terwijl men hieraan nog kan toevoegen, dat Dillard geen onderscheiding maakt tussen de markten van lang en kort vermogen. De rentevoet op de langvermogensmarkt is $4 \%$, maar het verschil ad $\$ 200$. - is inkomen waarvan slechts een gedeelte of in het geheel niets op de lang-vermogensmarkt wordt aangeboden.

Tenslotte kan men nog voorbehoud maken, dat er volgens deze theorie gelijkheid of ten minste een tendentie tot gelijkheid bestaat tussen mar-

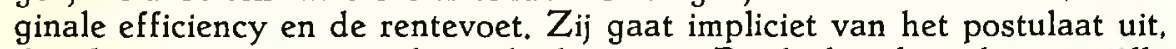
dat de rentevorming in de praktijk vrij is. Reeds het feit, dat niet álle investeringen gevoelig zijn voor de rentevoet, ontneemt aan Keynes' theorie veel van haar waarde. Keynes schenkt ook geen aandacht aan het verschijnsel van de auto-financiering. Het is een bekend feit, dat niet alle zakenlieden vrij zijn in hun keuze van belegging. Men kan twee groepen van beleggers onderscheiden: de Staat en de zakenlieden. Deze laatsten staan aan het hoofd van hun zaken, welke om zo te zeggen een eigen leven leiden. Hun economisch potentieel vereist uitbreidingen. Zulks brengt de ondernemer ertoe de voorkeur te geven aan het doen van beleggingen in zijn eigen onderneming en hiervoor zondert hij de nodige reserves af. Keynes heeft vooral de houders van de grote inkomens en de banken op het oog. Maar vertegenwoordigen deze het grootste deel van het aanbod van de koopkracht? $Z_{\text {ijn }}$ de banken er niet juist om de koopkracht van de gemiddelde ondernemingen aan te vullen en beschikken zij niet vooral over de deposito's van deze zelfde categorie? Om deze vragen te beantwoorden moeten wij vraag en aanbod van de koopkracht nader onderzoeken.

Beginnende bij de vraag, kan men 3 categoriën onderscheiden: de Staat, de bestaande firma's en de pas opgerichte firma's. De Staat treedt 
in concurrentie met deze ondernemingen op de kapitaalmarkt. Vanwege zijn positie bepaalt zijn aanbodprijs vaak de rentevoet. Van de andere kant treedt de Staat steeds op als koper van koopkracht, zodat iedere spaarder er zeker van is bij hem een beleggingsmogelijkheid te vinden. De redenen waarom de Staat als koper optreedt interesseren ons hier niet. Het is ons voldoende te weten, dat, zèlfs bij het ontbreken van iedere vraag van privé-zijde de spaarder een rente kan verkrijgen door zijn liquide middelen om te zetten in staatsfondsen. Het is derhalve duidelijk, dat de ondernemingen een hogere prijs moeten betalen dan de Staat waarvan de fondsen gegarandeerd en soms belastingvrij zijn. De redenen, welke de ondernemingen ertoe brengen koopkracht te vragen zijn tweeledig:

1. om het hoofd te bieden aan tijdelijke geldbehoeften (op lange of korte termijn); 2 . om het hoofd te bieden aan de omvangsuitbreiding van de onderneming, d.w.z. aan een vergroting van hun productiecapaciteit.

Voor het ogenblik vereist alleen dit laatste geval onze aandacht. In het algemeen zal de onderneming alvorens tot verhoging van haar capaciteit te besluiten reserves voor uitbreidingsdoeleinden gevormd hebben; deze echter kunnen onvoldoende zijn om het project te verwezenlijken. Anders gezegd, de mogelijkheid tot auto-financiering is dikwerf zwak. Merken wij allereerst op, dat deze reserves worden gevormd zonder ook maar enige rekening te houden met de rentevoet en voorts dat $z$ ij een vermindering van koopkracht betekenen van consumptie-standpunt bezien. Het is bovendien van belang op te merken, dat alle ondernemingen geen toegang hebben tot de officiële kapitaalmarkt, het merendeel is „,self-supporting". Dientengevolge speelt voor hen de rentevoet slechts een zeer bijkomstige rol. Deze ondernemingen zijn aangewezen op de goedwillendheid van de banken tot wie zij hun credietaanvragen richten. De rente, welke de banken hun berekenen, worden verhoogd met administratiekosten enz. Onder deze omstandigheden is er van een zuivere rentevoet geen sprake meer.

De vennootschappen, die voldoen aan het beursreglement, kunnen aandelen uitgeven. Wij vragen ons evenwel af, of men hier terecht van een rentevoet kan spreken. Immers door de uitgifte van aandelen beloven deze vennootschappen geen rente maar een aandeel in de winst waarvoor de inschrijvers het risico van de exploitatie op zich nemen. Daarom is het ook verkiezelijker te zeggen, dat de grootte van de te verwachten winsten het publiek tot inschrijving aanzet. De pas opgerichte vennootschappen moeten eveneens belangrijke winsten in ' $t$ vooruitzicht stellen, welke de gewone rentevoct verre overtreffen. Tenslotte dient men niet te vergeten, dat niet iedere spaarder in staat is om in te schrijven: de kleine en gemiddelde spaarders moeten zich tevreden stellen met inschrijvingen op fondsen met vast inkomen daar immers reeds zwakke koersschommelingen meer van hun kapitaal opsouperen dan de ontvangen dividenden bedragen.

Aldus kunnen wij 3 groepen van beleggingen onderscheiden:

1. de vervangingsbeleggingen;

2. natuurlijke beleggingen:

3. schumpeteriaanse beleggingen.

De vervangingsbeleggingen zijn geen beleggingen in eigenlijke zin daar zij dienen tot instandhouding van het capaciteitsvolumen en daaraan niets toevoegen. $Z_{i j}$ worden gefinancierd uit de afschrijvingen. 
De natuurlijke beleggingen beantwoorden aan hetgeen wij genoemd hebben de "het economisch potentieel" van de onderneming. Zij worden deels gefinancierd door toepassing van de methode van de auto-financiering, deels door een beroep te doen op de kapitaalmarkt.

Wat de schumpeteriaanse beleggingen betreft, zij worden aldus genoemd cmdat zij beantwoorden aan ,,de nieuwe combinaties" welke de betrokken ondernemers zich voornemen te verwezenlijken.

Het schijnt, dat de beleggingen van de tweede groep, voor zover zij een beroep op de vermogensmarkt doen, en die van de derde groep, gevoelig zijn voor de rentevoet. Uit bovenstaande volgt, dat de bewering van Keynes volgens welke álle nieuwe beleggingen voor de rentevoet gevoelig zijn, overdreven is.

De bronnen, waaruit de koopkracht voortvloeit, kunnen wij als volgt onderscheiden: 1 . de particulieren; 2 . de Staat; 3 . de banken. In tegenstelling met sommige auteurs zijn wij van mening, dat het niet noodzakelijk is, dat besparingen, in de zin van uitgestelde consumptie, niet voor belegging in aanmerking komen. Het maakt o.i. een groot verschil of de maatschappij al dan niet tot consumptie bereid is. Een verlaging van het consumptie-coëfficient zal een vergroting van de hoeveelheid koopkracht tot belegging bereid tengevolge hebben. Wij mogen dus een deel van de koopkracht, welke door de uitgestelde consumptie vrijkomt, als een bron van investering beschouwen. Prof. Kleerekoper heeft een diepgaande analyse gemaakt van het verschijnsel van de investering. $Z_{i j n}$ conclusie luidt, dat alleen een synchronisatie van besparingen (afstel van consumptie) mèt investering economisch rationeel is. In dat geval is de uitbreiding van de productiecapaciteit in overeenstemming met de besparingen, en, dit is het belangrijkste, iedere algemene overproductie is uitgesloten. Hieruit volgt, dat wij zeer sceptisch moeten staan t.a.v. de keynesiaanse inflatiepolitiek. ledere toegevoegde geldcreatie veroorzaakt nog niet automatisch een herleving van de economie, zij stimuleert niet noodzakelijkerwijze de ",propensity to consume". In de theorie van Kleerekoper wordt het prijsmecanisme in ere hersteld, terwijl in de General Theory zijn functie van regulisator wordt verwaarloosd of althans ondergeschikt gemaakt aan monetaire invloeden. In het licht van Kleerekoper's beschouwingen kunnen wij tot Keynes de critiek richten, dat hij het sparen en het investeringsverschijnsel niet voldoende heeft onderzocht. Volgens hem zou het voldoende zijn het investeren te forceren, immers het evenwicht tussen besparingen en beleggingen herstelt zich automatisch. Beleggingen ex ante evenwel veroorzaken prijsverhogingen en vervolgens prijsverlagingen. Sommige auteurs spreken van ..gedwongen sparen" waarmede zij deze prijsverhogingen op het oog hebben, maar de prijsverlagingen, welke noodzakelijkerwijze hierop volgen tengevolge van de vergroting van het aanbod worden veelal vergeten. Evenwel zijn de gedwongen besparingen, daar zij in zich geen reële besparingen zijn, logischerwijze niet tot concrete financiering van de investering in staat. De egalisatie van besparing en belegging ex post is dan ook naar onze mening oogbedrog. Inderdaad neemt, zodra de nieuwe productiecapaciteit in werking is getreden, het aanbod van gebruiksgoederen toe zonder dat evenwel de inkomens noodzakelijkerwijze toenemen. Dit zal nu onvermijdelijk tot een prijsverlaging en tot verlies van vermogen leiden. Het hogere prijsniveau verdoezelt het feit, dat de reële besparingen niet gelijk zijn geweest aan de beleggingen. In monetaire termen uitgedrukt kan $I=S$, maar het is zer twijfelachtig of dit ook in reële termen zo is. 
Richten wij onze blik nu tot de ondernemingen zelve. Een fundamenteel principe is, dat de ondernemer slechts dan investeert, wanneer de productiemiddelen een product opleveren, dat tegen een hogere prijs dan de kostprijs op de markt verkocht kan worden. Hieruit volgt, dat, wanneer de capaciteit van de maatschappelijke productie voldoende is, het, zoals Kleerekoper opmerkt, een grove fout is deze te vergroten, daar immers de nieuwe productie geen afzet tegen redelijke prijzen zal kunnen vinden.

Resumerende kunnen wij dus vaststellen, dat de analyse van Keynes onvoldoende is met betrekking tot de economische verschijnselen binnen de bedrijfshuishoudingen, zelfs wanneer deze een directe invloed uitoefenen op de sociale economie. Verder, Keynes heeft het begrip vervangingswaarde gebezigd in enge bepaalde zin, hetwelk in feite neerkomt op dat van de historische kostprijs. Doordat hij niet heeft ingezien, dat de vervangingswaarde een allerbelangrijkst element vormt, kleeft aan zijn theorie hetzelfde euvel als aan de andere conjunctuurtheoriën t.w. het waardebegrip als een historisch gegeven te beschouwen en uit een nominaal verschil tussen historisch en werkelijke waarden de conjunctuur te willen verklaren. Het is de grote verdienste van Limperg aan het begrip vervangingswaarde een theoretische èn practische inhoud te hebben gegeven. Het valt te betreuren, dat de Nederlandse sociale economen aan deze theorie niet die aandacht hebben geschonken, welke zij verdient.

Zoals alle menselijk werk is ook dat van Keynes onvolmaakt, maar zijn naam zal steeds vereeuwigd blijven als van degene, die een ware revolutie in onze wetenschap heeft teweeg gebracht. Hierdoor is het volle licht komen te vallen op de interdependentie van alle economische krachten.

Tot slot mogen wij besluiten met het geestig woord van Jean Marchal aan te halen in de aanhef van zijn "Cours d'Economie politique": .Non, toute l'économie politique n'est pas contenue dans Value and Capital de J. R. Hicks, si grand que soit cet auteur! Si l'on tient absolument a tout rapporter à un seul livre, ce qui est enfantin, nous préférons la Théorie Générale de J. M. Keynes car elle contient de l'humour et une suffisante obscurité, avec cela, on peut reconstituer notre monde.

1) Geciteerd uit "Les fluctuations êconomiques" van Prof. Henri Guitton. - Serey Paris 1951. 1952.

2) Prof. A. Barrère ..Théorie économique et impulsion keynésienne" Dalloz-Paris

3) „The economics of John Maynard Keynes" London 1948, p. 11.

4) In de franse versie van dit artikel hebben wij op deze constatering het fondamentale verschil gevestigd tussen de onderscheiden waarden. De producent beoordeelt de waarde niet in functie van zijn directe behoeften, maar in functie van het inkomen, dat hij wenst te trekken uit zijn activiteit. Bij de consument is de economische activiteit gericht op de onmiddellijke behoeftenbevrediging. Hieruit volgt, dat de Oostenrijkse theorie van de prijsvorming twee hetegorene waardeoordelen met elkaar vergelijkt. In voorbeeld van de paarden van von Böhm-Bawerk wordt het waardeoordeel van de koper en van de verkoper als gelijkwaardig gesteld, op de redenen van hun handelen wordt niet nader ingegaan hetgeen de indruk wekt, dat de verkoper op dezelfde wijze reageert als de koper.

5) S. Kleerekoper „Beginselen der Bedrijfseconomie” dl. I p. 11.

6) Het schijnt ons toe, dat het wenselijk is hier niet van een "norm" te spreken. Deze term heeft $\mathrm{nl}$. een ethische inhoud welks gebruik verwarrend zou kunnen werken, daar niet alle economen onze wetenschap wertfrei opvatten. Daar de bedrijfseconomie absoluut 
wertfrei is ( $z \mathrm{ij}$ is misschien de enigste tak van de economische wetenschap waar het economisch beginsel het gehele denken beheerst) is derhalve de term ,regel" meer op haar plaats.

7) De theoriën van een collectief bewustzijn, zoals een Dürkheim of Levy-Bruhl die ontwikkeld hebben vonden geen algemene instemming. De collectieve verschijnselen, waarop deze theoriën berusten, bewijzen het bestaan van een specifiek sociaal bewustzijn niet.

8) Om ieder nisverstand te voorkomen zij er nadrukkelijk op gewezen, dat onder normatieve wetenschappen hier verstaan dienen te worden die wetenschappen, welke in een bepaald verband met elkaar staan en wel een verband dat een appreciatie inhoudt. De physica en chemie staan in een technisch verband tot elkander, maar de een is niet ondergeschikt aan de ander. Tussen economische en sociale waarde-oordelen bestaat wel deze hiërarchie. De moeilijkheid is hier, dat de economie tweeslachtig is; enerzijds is zij analytisch en als zodanig bestaat er geen hiërarchisch verband met de sociologie, anderzijds stelt $z \mathrm{ij}$ ons in staat een bepaald doel te bereiken en met betrekking tot de appreciatie van dat doel bestaat dit hiërarchisch verband wel.

9) Deze opvatting is eigenlijk zeer eigenaardig bij een schrijver die zulk een groot gewicht hecht aan de dynamische factoren in de economie. De historische kostprijs toch is essentieel statisch. Een theorie die de kostprijs niet dynamiseert (vervangingswaarde!) hinkt op twee benen, wanneer zij wil, dat de andere begrippen wel dynamisch moeten worden opgevat.

10) Stel het geval, dat veelvuldig in Frankrijk is voorgekomen nl. dat van salarisverhogingen met terugwerken de kracht.

11) Men kan zich trouwens bij het lezen van de General Theory niet aan de indruk onttrekken, dat Keynes de vermogensmarkt als onuitputtelijk beschouwt. 